\title{
A Survey Study on the Application of Modern Educational Technology in English Major College Teaching in the Age of 5G Communication*
}

\author{
Yuhang Gao \\ College of Foreign Language, Yanbian University, Ji Lin, Yan Ji, China
}

\begin{abstract}
G, the fifth generation of mobile communications technology, is the latest generation of cellular mobile communications technology, with high data rates, reduced latency, energy savings, reduced costs, increased system capacity and large-scale device connectivity. The Ministry of Education had made the integration of information technology and education and teaching development as a key task in 2018, and the arrival of the 5G era has also provided a greater development space for modern education technology, which has brought greater opportunities and challenges for education and teaching. Based on the existing research, this paper takes English major in a university in Northeast China as an example to investigate and analyze the application of modern educational technology in English majors in the 5G era, including the following aspects: 1) the comprehensive ability of English majors; 2) the application of modern educational technology in English major teaching; 3) the students' understanding of modern educational technology; 4) the advantages and disadvantages of the application of modern educational technology in the teaching of English majors; 5) the suggestions of English major students themselves about the application of modern educational technology in the major class learning. Then through the analysis of the survey results, the study thinks about how to make modern educational technology more effective, and combines with the traditional teaching means, puts forward suggestions for better application of modern education technology in English major teaching in the future, so as to promote the improvement of students' comprehensive quality and professional teaching effect.
\end{abstract}

Index Terms-5G, modern educational technology, English major teaching

\section{INTRODUCTION}

\section{A. Research Background}

$5 \mathrm{G}$ is a shift from one quality to another in the big data era, it is a comprehensive and multi-domain change. The arrival of $5 \mathrm{G}$ era means not only faster network speed, but also a rapid development of technological change and information exchange. The Ministry of Education clearly put forward the key task of promoting the integration of information technology and education in key points for education informatization and cybersecurity work in 2018. Also, the combination of modern educational technology and professional teaching is in line with the requirements of "changing the concept of education, deepening the reform of education, strengthening the construction of teaching and improving the quality of teaching" mentioned in the Opinions on Deepening the Reform of Teaching and Cultivating High-quality Personnel to Meet the Needs of the 21 st Century.

Therefore, the combination of education and modern technology is irreversible in the era of 5G, especially the English major, which with the main goal of cultivating international talents should conform to the trend of the times, make good use of the characteristics of high speed, low delay, low power and wide connection of modern information technology in the 5G era, apply modern educational technology to professional teaching actively and give full play to its advantages. In this way, applying modern education technology in English teaching can help English majors broaden their international horizons, enhance their English skills, and further improve their teaching results.

\section{B. Research Purpose and Significance}

On the basis of the existing research, this paper investigates and analyzes the current situation of applying modern education technology in English majors, and weighs the advantages and disadvantages, aims to explore how to combine modern educational technology with traditional teaching methods in the $5 \mathrm{G}$ era, so as to achieve the purpose of improving the interest and efficiency of English learning of English majors, broadening students' international horizons and enhancing students' personal English literacy.

\footnotetext{
* This research was supported by the research funds of "Research Innovation Project of College Students in Yanbian University" ([2019], No. YDCXCY2019067) 


\section{The Organization of the Study}

Through literature research and questionnaire survey, this paper investigates the present situation of English major teaching and the application of modern education technology in the English teaching of a university in Northeast China. By consulting the relevant literature and combining with the actual situation of the university, the questionnaires was designed, and the results of the survey will be summarized and put forward, so as to better apply modern education technology to the professional teaching to improve the efficiency and teaching effect of English major.

The survey included 250 questionnaires in total, recovery 232 valid questionnaires, including 66 freshman, 69 sophomores, 57 juniors and 40 seniors. The questionnaire researches the following aspects: 1) the students' English listening, speaking, reading and writing abilities; 2 ) the situation of applying modern educational technology in English major; 3) the students' understandings of modern educational technology; 4)the advantages and disadvantages of applying modern educational technology; 5) the students' suggestions on applying modern educational technology.

By analyzing the results of these questionnaires, the study made a conclusion from such five aspects and put forward suggestions for the application of modern educational technology in English major teaching.

\section{LITERATURE REVIEW}

\section{A. Conceptual Definitions of Key Terms}

Generally speaking, $5 \mathrm{G}$ means the $5^{\text {th }}$ generation mobile networks, its peak theoretical transmission speeds are up to $1 \mathrm{~GB}$ per 8 seconds, hundreds of times faster than that of a $4 \mathrm{G}$ network. $5 \mathrm{G}$ network aims at providing high data rates, reducing latency, saving energy, lower costs, increasing system capacity and large-scale connectivity. In the era of 5G, it will be more convenient and faster to access information, thus, it'll provide great chances to the development of modern education technology.

As for modern educational technology, it was first put forward in the United States in 1930, and began to be mentioned and used in China after 1980. The viewpoints about the modern educational technology are not all the same, however, it can be generally defined as the process of designing, developing, applying, managing and evaluating teaching by applying modern information technology and modern educational concept, so as to realize the optimization of teaching theory and practice. There are two elements in it, the first is the modern educational ideology and theory, and the second is the modern informational technology and system methods. Usually, the modern education technology including Virtual Reality (VR) and Augmented Reality (AR) which can create and experience the virtual world, and integrate the virtual world into the real world for interaction, immersing the user in the environment, and on-line courses such as MOOC, i.e. large open web courses, free courses offered on web-based learning platforms by institutions of further learning, with a wide range of courses and more emphasis on interaction with students.

Therefore, the application of modern education technology in English major teaching in the era of 5G can make full use of the characteristics of 5G such as high transmission speed, broad dissemination, low delay and energy savings. The proper use of modern educational technology can greatly save teaching resources, improve teaching efficiency and give students more space and chances for autonomous learning.

\section{B. A Description of Related Studies with Evaluation Comments}

Today, with the rapid developed technology and the globalization, it's imperative to apply the modern educational technology in English major teaching to broaden students' international horizons and improve their English acquisition ability.

Many scholars at home and abroad have made substantial researches on the application of modern educational teaching technology in English teaching, the literature on modern education technology has been nearly 100,000 articles from 2015 to the beginning of 2019, and it is increasing year by year. The abroad scholars such as Marina, D. (2007), Gutareva, N. Y. (2014), Olga Vitalievan Sumtsova and Tatiana Yurievna Aikina (2015) focus on the modern educational technologies applied in foreign languages acquisition, and the scholars at home such as Liu Wei (2013), Li Jingyun (2016) and Zhang Lingzhi (2017), start their researches on the foundation of analyzing the current situation of the application of modern educational technologies in education. Their studies can be categorized from the following four aspects:

First, study is done on the foundation of researching the current situation of the application of modern educational technology and the English teaching. It has reached a consensus that the application of modern educational technology not only injects vitality, but also brings unprecedented opportunities and challenges to English teaching. The differences between different scholars' viewpoint is that they concern about the different aspects of English teaching.

For example, Liu Wei (2013) concerns about the limitation of traditional education model, he points out that students who learn under the traditional model spend a lot of time and energy to memory words and grammar only result with "mute English" and "deaf English" . And Li Jingyun (2016) reveals that the main models in China's English teaching, including traditional English teaching model, traditional English teaching model assisted by multimedia, and classified English teaching model, still belong to the teacher-centred model. In the mean time, Sun Huali (2016) emphasizes that English teaching in colleges does not make full use of Internet technology, abundant information and efficient advantages, still limited by the traditional educational model. Fedyanin, A. B. (2017) believes the application of modern educational technology can realize high efficient methods of education. 
Second, the study is done on the positive effects of the application of modern educational technology. The advantages are mainly talked from two aspects, the learning aspect and teaching aspect. From the perspective of learning, Zhao Huichen (2009) mentions that it can help cultivate students' creative thinking, so that they can complete the task of English autonomous learning independently. And Zhang Huifeng (2016) adds that it can promote students' listening and speaking ability.

From the perspective of teaching, Sun Huali (2016) proposes that it can effectively improve the English curriculum level and play a certain role in promoting the construction of English teaching staff. Moreover, some scholars pay attention to more specific contents, such as Zhang Lingzhi (2017) takes the modern educational technology as the auxiliary teaching means of traditional education to innovate college English teaching methods. Sheng Li (2018) finds out it can share high quality teaching resources, increase equal and fair opportunities for English education, train English professionals to meet the needs of internationalization. And the application of modern educational technology can raise students' interests in English learning, improve the quality of teaching in the research of Zhao Dan (2018).

Third, the study is done on the negative effects of the application of modern educational technology. In this part, people's viewpoint can be concluded to three aspects: students, teachers and resources.

Li Jingyun (2016) divides the negative effects into three parts, the first part is the weak consciousness of autonomous learning of students, they lack of self-management and planning awareness, most of them most of time accustom to the passive acceptance and obedience. The second part is the limited hardware facilities, the network platform learning is limited by computer and network conditions, this makes it very inconvenient to study. The third part is lack of management means and technology, on the one hand, teachers lack training in educational techniques and data analysis, on the other hand, here are more or less loopholes the current test system.

Furthermore, Zhang Lingzhi (2017) also states the problems from three aspects, the first is the distraction of students, there is too much information on the Internet, students can be easily attracted by somethings irrelevant to study. The second is the over-reliance on modern educational technology of some teachers and students, it is obviously unscientific to ignore the importance of teachers and students in education. Third aspect is the inundation of teaching resources, it is difficult to screen and utilize these resources correctly and effectively in the process of English teaching. Another scholar, Sheng Li (2018) concludes the challenges for traditional teaching in the process of applying modern educational technology in English teaching. In her viewpoint, the teaching methods, teacher's role in teaching, and students' learning concepts and styles are all challenged.

Most of scholars notice the positive effects of modern educational technology in English teaching, but rarely concern about the negative effect, as a result, modern educational technology cannot be made full use of in the process of English teaching, and it's hard to popularize and use in a large range.

Forth, study is done on the application strategies of modern educational technology in English teaching. How to apply the technology well in the process of teaching is a question for both English educators and learners to think about, and this is the most critical in English education. Liu Wei (2013) proposes to make full use of foreign language media resources to create multi-environment foreign language acquisition, and try to make the scientific human-computer interaction model as an integral part of English listening and speaking teaching. Meanwhile, Wang Ting (2013) recommends to create a great learning environment through multimedia technology, she also mentions the curriculum model of students' autonomous learning with the support of modern education environment, such as microteaching.

Besides, there are some scholars give some more specific arrangements about the application of modern educational technology. Zhao Dan (2018) puts forward to apply multimedia teaching technology and Internet distance teaching in English teaching. Multimedia courseware can change the abstract teaching content into concrete and visualized, highlight the key points and simplify the difficulties so that students can understand and master the knowledge easily, and then promote the teaching efficiency and quality of the class. As for Internet distance teaching, it is not limited by time and place so that students can learn online according to their own needs and learn content, in this way, the speed of information dissemination and the efficiency of learning information are improved in a great degree. Moreover, some scholars prefer to flipped classroom. After years of practice, some concrete teaching models about flipped classroom have been formed.

Today, we are in an era of rapid development of science and technology and economic globalization. The application of modern educational technology to teaching is the inevitable trend of the development of education, especially the English major, which cultivates international talents. By analyzing the current situation of English teaching, many scholars have studied the problems existing in English teaching and the problems that might brought by the application of modern educational technology, and then to find out the corresponding application strategies.

In all, the English major teaching still tends to be traditional, and people know not much about modern educational technology, as a result, the application of the technology in English major teaching will face great challenges while there are great opportunities for the future development of it. Through the investigation and analysis of the specific situation can maximum the advantages brought by modern educational technology in English majors. The application of modern educational technology is quite popular now, it brings great influence to education reform and stimulates the innovation of teaching methods. Although there is not much research experience of former scholars, it gives us more space to explore. 


\section{METHODOLOGY}

The research mainly focuses on literature research and questionnaire survey. The subjects of the survey are undergraduates majoring in English majors, and the number of students surveyed in each grade is relatively balanced. The content of the questionnaire includes the student's English comprehensive ability, the level of understanding of modern educational technology, the application of modern educational technology in their professional learning, and the student's suggestions on applying modern educational technology in the study of professional courses. The design is more comprehensive, but there are some problems in the investigation process, such as the students scattered which made investigation become more difficult, and the students' attitude towards the investigation is not serious enough.

In recent years, many experts and scholars at home and abroad have done research on the combination of modern education technology and education and teaching, there are nearly 100,000 literature studies on modern education technology from the beginning of 2015 to the beginning of 2019, and it'll increase year by year. However, the researches on modern educational technology in English teaching is very few, no more than 60 articles in five years, and it's hard to see the consideration about the application under the era of 5G. It provides little valuable information for the research.

\section{RESEARCH AND DISCUSSION}

\section{A. The Students' English Comprehensive Ability}

This paper has researched the condition of students' English comprehensive ability, including listening, reading, speaking and writing four aspects. Students' English ability has been divided four levels, and decrease from A to D. From the following table, it can be found out that most of students' English reading and writing ability is quite great, and is better than their English listening and speaking ability, while most of students' performance in English listening and speaking is not so optimistic .The reasons for this phenomenon may be related to the students' learning environment, or the teacher's teaching methods, the traditional teaching methods more to exercise students' reading and writing skills but less to develop students' language communication skills, which can easily cause deaf English, dumb English and so on. Therefore, applying the modern educational technology into English major's teaching to improve students' English listening and speaking ability is quite necessary.

TABLE 4-1

STUDENTS' ENGLISH COMPREHENSIVE ABILITY

\begin{tabular}{|c|c|c|c|}
\hline \multicolumn{2}{|c|}{ listening } & \multicolumn{2}{|c|}{ reading } \\
\hline $\mathrm{A}$ & $3 \%$ & $\mathrm{~A}$ & $4.5 \%$ \\
\hline $\mathrm{B}$ & $34.5 \%$ & $\mathrm{~B}$ & $54.5 \%$ \\
\hline $\mathrm{C}$ & $52.5 \%$ & $\mathrm{C}$ & $36.5 \%$ \\
\hline $\mathrm{D}$ & $10 \%$ & $\mathrm{D}$ & $4.5 \%$ \\
\hline \multicolumn{2}{|c|}{ speaking } & \multicolumn{2}{|c|}{ writing } \\
\hline $\mathrm{A}$ & $2 \%$ & $\mathrm{~A}$ & $5.4 \%$ \\
\hline $\mathrm{B}$ & $34 \%$ & $\mathrm{~B}$ & $45.8 \%$ \\
\hline $\mathrm{C}$ & $55.5 \%$ & $\mathrm{C}$ & $45.8 \%$ \\
\hline $\mathrm{D}$ & $8.5 \%$ & $\mathrm{D}$ & $3 \%$ \\
\hline
\end{tabular}

\section{B. The Application of Modern Educational Technology in English Major}

Surveying the teaching methods that students are frequently exposed to in the study of professional courses, with a total of 15 possible options for students to choose from, including classroom lectures, student presentation, group discussion, multimedia teaching, social practice, situational teaching, flipping classroom, online writing system teaching, online course teaching, online and offline mixed course teaching, spoon-feeding, all kinds of cloud class teaching, micro-teaching, virtual simulation course teaching and others provided by students.

According to the survey results (Figure 4-1), the four teaching modes that English majors are most exposed to in the course of study are classroom lectures (99\%), student presentation (93.5\%), group discussion (93.5\%) and multimedia teaching $(83 \%)$, and the rest modes are not common. However, it is well known that these four kinds of teaching methods seldom apply modern education technology in their teaching process, most of them belong to the traditional teaching mode, which has limited effect on training students' English comprehensive ability, as for the modern educational technology, is less used in the classroom teaching of English majors, so that students and teachers in English majors cannot make full use of the convenience provided by the rapid development of modern educational technology under the $5 \mathrm{G}$ era. 


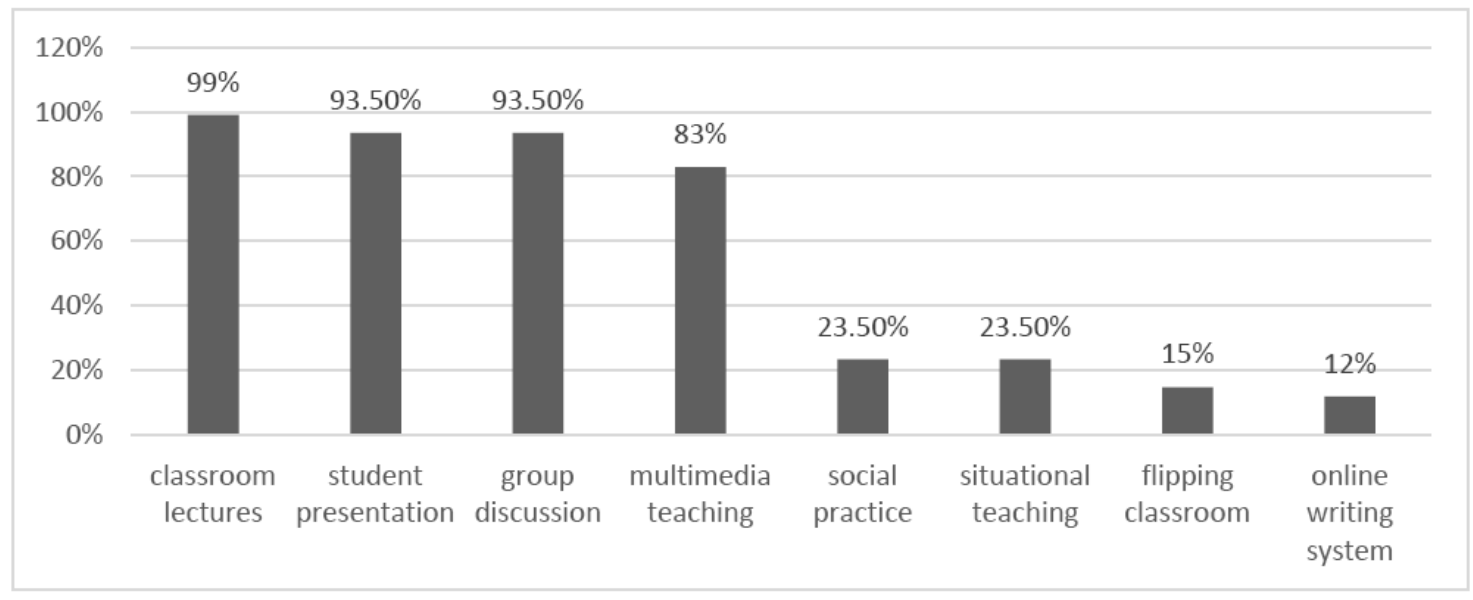

Figure 4-1 Common Teaching Models in English Major Teaching

\section{The Understanding of Students about Modern Educational Technology}

When researching the understanding of students about modern educational technology, most of students believe that classroom lectures (92\%), spoon-feeding (42\%), group discussion (42\%) and students presentation (40.5\%) belong to traditional education model (Figure 4-2 Traditional Teaching Model), and multimedia teaching (66\%), virtual simulation course teaching $(61 \%)$, online course teaching $(53.5 \%)$ belong to teaching model which applying modern educational technology (Figure 4-3 Teaching by Modern Educational Technology).

This proves that these English majors have some knowledge of modern educational technology, but limited by the teaching environment and teaching conditions, it is difficult to have a better understanding and contact with modern educational technology. However, in the era of 5G, the rapid development of modern education technology provides a great deal of learning resources and sufficient learning space for education and teaching. The students' contact and cognition of modern education technology are limited, which also affects the students' learning effect to a certain extent, especially the students majoring in English, they need to make good use of the convenient network communication technology, understand the international current affairs, open up the international vision, improve their English comprehensive quality in an all-round way, rather than only study the basic English ability.

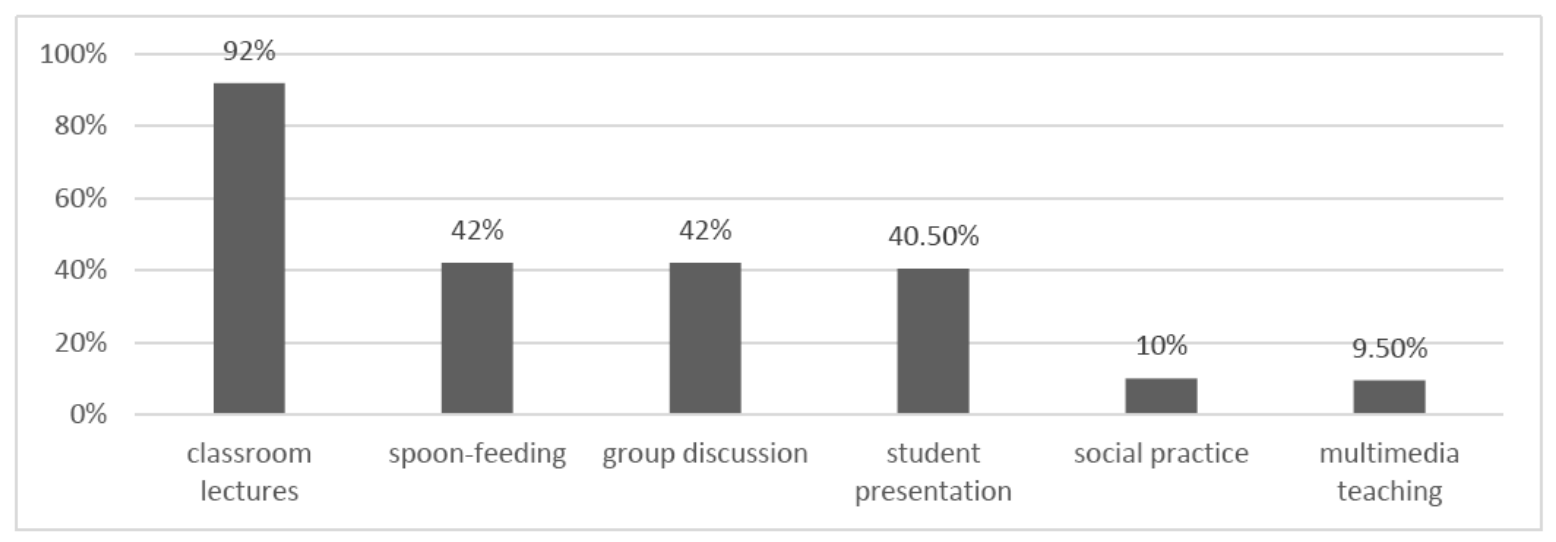

Figure 4-2 Traditional Teaching Models 


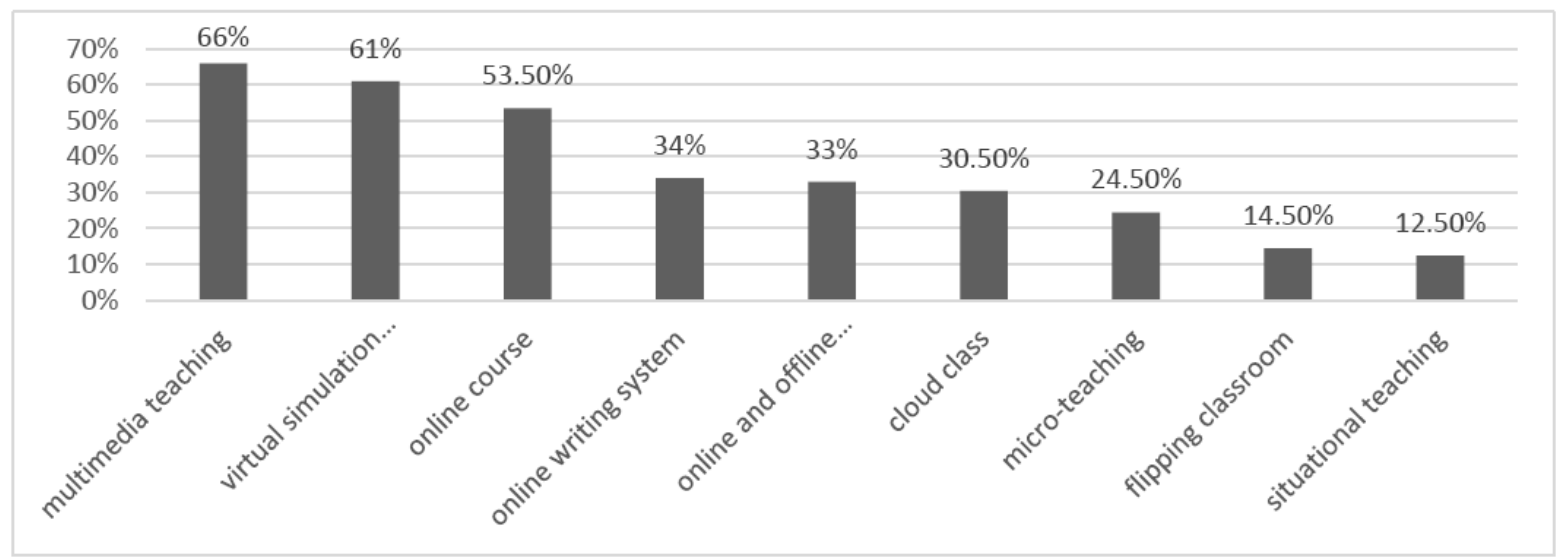

Figure 4-3 Teaching by Modern Educational Technology

From the perspective of students, they believe the combination of traditional teaching methods and modern education technology can promote students' English learning effect and English comprehensive ability more effectively than a single model to improve their English proficiency, the four most popular methods are situational teaching (40.5\%), student presentation(35.5\%), classroom lecture(31\%) and social practice(28\%). Analyzing from the data of Figure 4-3 Teaching Models Could Improve Students' English Effectively, it can be found in the process of learning English, students pay more attention to the combination of traditional teaching and modern educational technology, and the combination of theoretical study and social practice.

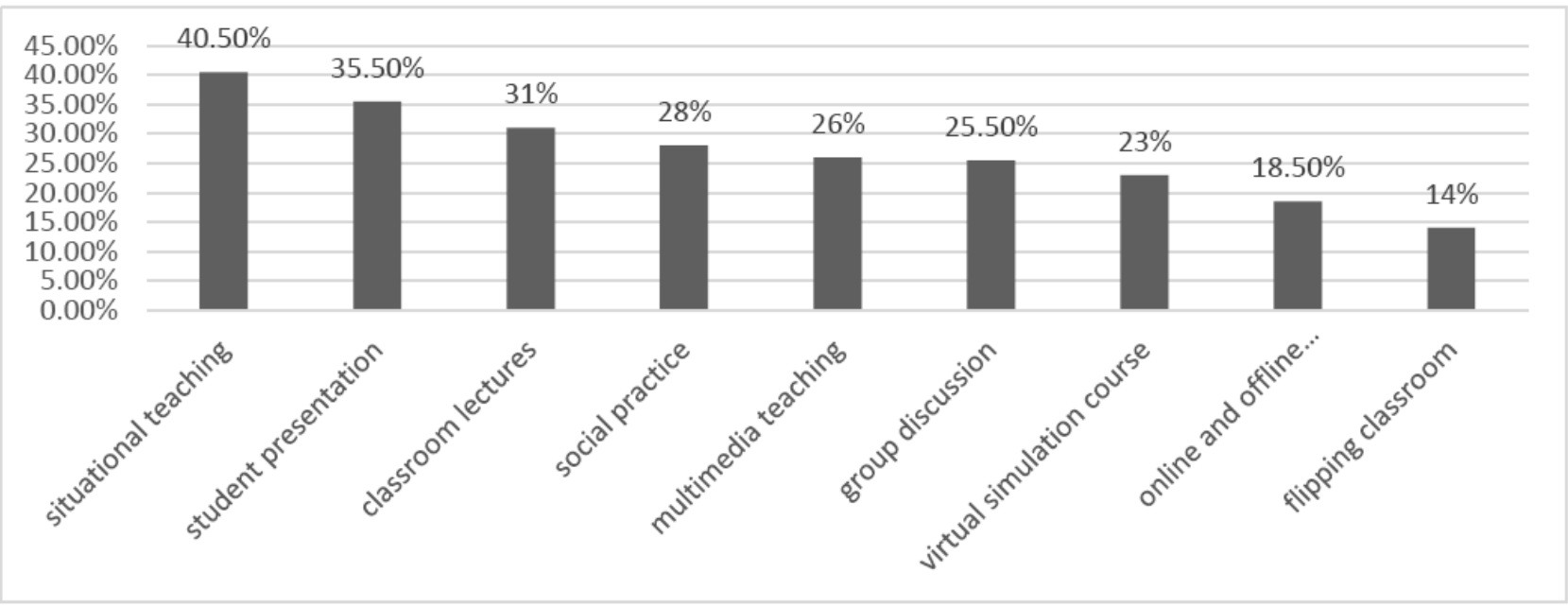

Figure 4-4 Teaching Models Could Improve Students’ English Effectively

\section{The Effects of Applying Modern Educational Technology}

\section{The Advantages of the Application}

According to the research, students proposed six main advantages of applying modern educational technology in the English major teaching as Table 4-2, the three most recognized advantages are to enrich learning resources (75.5\%), cultivate students' self-learning ability (65\%), and improve students' learning enthusiasm (54.5\%). Exactly, the application of modern education technology in the teaching of English majors can enrich students' learning resources. With the arrival of 5G era, the speed of information transmission is greatly improved, and a large group of education platforms can provide a large number of learning resources, so that students can easily obtain the learning resources of famous schools that they have no chance to get into in reality. About cultivating students' self-learning ability, in the 5G era, all kinds of teaching software and teaching platforms are springing up, and teachers and students can teach and study even thousands of miles away, which provides students with a more free and diverse choice of learning time and learning space.

As for improving students' learning enthusiasm, the cloud class software usually sets up incentive mechanism, teachers can use these software to issue learning tasks on a regular basis, students complete according to the regulations, according to the quality of completion and other comprehensive factors to score, give appropriate rewards. Students can also use software to practice together, such as word memory competition, English reading proficiency test, practical scene simulation dialogue practice, through the reward and competition mechanism to stimulate students' interest in learning, promote students to learn actively so as to improve students' learning efficiency. 
TABLE 4-2

THE ADVANTAGES OF THE APPLICATION

\begin{tabular}{|l|c|}
\hline Enriching learning resources & $75.5 \%$ \\
\hline Cultivating students' self-learning ability & $65 \%$ \\
\hline Improving students' learning enthusiasm & $54.5 \%$ \\
\hline Enhancing students' practical ability & $36.5 \%$ \\
\hline Enhancing students' cooperation ability & $31.5 \%$ \\
\hline Developing the ability of solving problem & $29.5 \%$ \\
\hline
\end{tabular}

2. The Disadvantages of the Application

According to the research, students proposed five main disadvantages as Table 4-3, the most common disadvantage they agrees is students' excessive reliance on the modern educational technology (58\%). The arrival of the 5G era provides a broad space for the development of modern education technology, and modern education technology provides convenience for professional teaching, but if excessive use will lead teachers and students to rely too much on modern education technology, thus neglecting the subjectivity of teachers and students in the teaching process and the importance of teaching materials, then losing the original significance of teaching with the help of modern education technology.

TABLE 4-3

THE DISADVANTAGES OF THE APPLICATION

\begin{tabular}{|l|l|}
\hline Excessive reliance on the technology & $58 \%$ \\
\hline Uneven quality of learning resources & $47.5 \%$ \\
\hline Students need acceptance process & $37.5 \%$ \\
\hline Distract students' attention & $35 \%$ \\
\hline Higher costs of the technology & $31 \%$ \\
\hline
\end{tabular}

\section{E. The Students' Suggestions on Applying Modern Educational Technology.}

By analyzing the collections of research data, it can be easily found out that students support for the application of modern educational technology in English majors much more than opposition, there are three main suggestions, including the proper combination of traditional teaching and modern education technology could increase students' participation in the classroom; increasing practical training to improve students' practical English application ability; making more use of modern educational technology to make class more interesting, enhance students' interests in learning, and thus improve students' English learning efficiency.

\section{CONCLUSIONS}

\section{A. Major Findings}

In conclusion, the students of English majors have good English literacy as a whole, their English reading and writing level is better than that of listening and speaking level. They have a certain understanding for modern educational technology, and they have a considerable expectation for applying modern educational technology in the study of professional courses. They believe that the modern educational technology can be used to obtain the teaching resources of various network platforms to enrich the students' learning resources, and that the long-distance teaching system can be used to cultivate the students' autonomous learning ability. And they agree that $5 \mathrm{G}$ will provide more diversified development for modern educational technology, and various modern educational technologies can effectively improve the students' learning enthusiasm and thus improve their learning efficiency. At the same time, there are concerns that students may be too dependent on modern educational technology to meet their expected teaching goals. That's what need to be considered in the future application of modern educational technology in English major.

\section{B. The Application Strategies of Modern Educational Technology}

First, applying modern educational technology with traditional teaching model moderately. Modern education technology is in the stage of rapid development in the era of 5G, still needs to be improved. So the application of modern education technology in the teaching process of English major requires teachers and students to work together, strengthen self-control to prevent excessive dependence, make full use of the convenience of modern education technology to assist professional teaching, promote the mutual communication between teachers and students, so as to train students' self-learning ability and then to improve learning efficiency.

Second, strengthening English practice step by step. Educational informatization is the inevitable trend of educational development in the future, but it still needs a long process to make effective use of modern educational technology in education. In view of the present situation of English major teaching, most students hope that the school can increase teaching aids and strengthen practical teaching. Nowadays AR/VR technology is developing well, with the development of $5 \mathrm{G}$ technology, AR/VR technology will become more and more mature, AR/VR technology could simulate foreign language communication situation and exercise students' English practical application ability.

Third, Strict regulation can ensure the quality of learning resources. The $5 \mathrm{G}$ era means faster network communication speed and more abundant and convenient network resources, making good use of this characteristic of the $5 \mathrm{G}$ era in the 
process of English major teaching can help students obtain more learning resources and meet the learning needs of different students. Now the network teaching platform is developing rapidly, all colleges and universities actively launch the excellent courses for students to learn, strengthen the supervision of online teaching resources, ensure the quality of resources, help students to choose the courses suitable for their own, and achieve the effect of teaching students according to their aptitude.

In conclusion, with the arrival of the $5 \mathrm{G}$ era, modern educational technology is developing more and more rapidly, and applying it to teaching will become the inevitable trend of education development in the future. As the main position to train international talents, English majors should conform to the trend of the times, apply modern educational technology to English teaching to promote the development of students' ability in all aspects.

\section{ACKNOWLEDGMENTS}

First of all, thanks to the patient guidance provided by professor Cui Xuebo, professor Cui has profound knowledge and rigorous scholarship, gave me firm encouragement and support in the continuous improvement of the paper, helped me to gradually complete the project; second, thanks to the 2019 innovative entrepreneurship training project team to provide financial support to ensure the smooth progress of the project; and finally thanks to all the people who have provided support and help to me during the completion of this project, so that the project can be successfully completed.

\section{REFERENCES}

[1] Gutareva. N. Y. (2014). Information Technologies in Modern Language Education. Krasnoyarsk Science, (16), 111-118.

[2] Gutareva. N. Y. (2014). Role of Modern Technology in Language Education. In the World of Scientific Discoveries / V Mire Nauchnykh Othkrytiy, (11), 253-263.

[3] Li Jingyun. (2016). Research on the Constraints of College English Autonomous Learning under the Environment of Internet. Higher Education Research, (10), 5-6.

[4] Liu Wei. (2013). Research on the optimization of college English listening and speaking teaching based on modern educational technology. China Audio-visual Education, (10), 116-119.

[5] Marina, D. (2007). Artificial Intelligence in Second Language Learning: An Efficient Approach to Error Remediation. Language Awareness, (2), 99-113.

[6] Olga,V. S. , Tatiana, Y. A. (2015). Applying Modern Educational Technologies in Foreign Language Teaching the Students of Technical Universities. V Mire Nauchnykh Othkrytiy, (59), 4263-4277.

[7] Sheng Li. (2018). Research on teaching practice reform of college English majors under the background of Internet era. Journal of Jilin Radio and Television University, (4), 42-44.

[8] Wang Ting. (2013). On the organic combination of modern educational technology and college English teaching. New West, (Z1), 216+221.

[9] Yong Zhao. (2003). A Comprehensive Review of Research on Technology Uses in Language Education. The CALICO Journal, (1), 7-27.

[10] Zhang Huifeng. (2016). The optimization strategy of modern educational technology in college English listening and speaking teaching. Journal of Yanbian Institute of Education, (04), 29-32.

[11] Zhang Lingzhi. (2017). The application of modern educational technology in college English teaching reform. Subject and Teaching (Education Development Research 2017 Supplement), (S1), 85-87.

[12] Zhao Dan. (2018). The application of modern educational technology in teaching. Economic Outlook around the Bohai, (3), 184-185.

[13] Zhao Jun. (2015). On the application of modern education technology in middle school English teaching reform. Modern Communication, (8), 212.

Yuhang Gao, born in Jilin, China in 1998. She received her B.A. degree in English language literature in Yanbian University, China in 2020. Her research interest is the English language and literature. 